\title{
Geology and U-Pb geochronology of the Annidale Group, southern New Brunswick: Lower Ordovician volcanic and sedimentary rocks formed near the southeastern margin of lapetus Ocean
}

\author{
M.J. McLeod, A.A. Ruitenberg \\ Department of Natural Resources and Energy, Geological Surveys Branch, P.O. Box 1519, \\ (Picadilly Road), Sussex, New Brunswick EOE 1P0, Canada \\ and \\ T.E. Krogh \\ Department of Geology, Royal Ontario Museum, 100 Queen's Park, Toronto, Ontario M5S 2C6, Canada \\ Date Received January 22, 1992 \\ Date Accepted April 21, 1992
}

\begin{abstract}
Geological mapping and $\mathrm{U}-\mathrm{Pb}$ (zircon) dating have led to the discovery of distinctive Lower Ordovician volcanosedimentary rocks in the Annidale area of southern New Brunswick. These rocks are included in a newly defined group, herein termed the Annidale Group, which is divided into three fault bounded(?) units of partially overlapping age. These units are named the East Scotch Settlement Formation, the Lawson Brook Formation and the Canaan Forks sequence, from south to north. The East Scotch Settlement Formation contains a steeply dipping succession of mixed mafic and felsic volcanic rocks and a variety of clastic and volcanogenic sedimentary rocks. The Lawson Brook Formation constitutes a shallowly to moderately north-dipping succession dominated by felsic volcanic rocks. The Canaan Forks sequence, most of which constitutes a shallowly to moderately north-dipping succession, is dominated by clastic sedimentary rocks. Structurally, much of the Annidale Group is characterized by intense shearing produced by numerous vertical northeast- and northwest-trending faults and by southward- and northward-directed thrust faults. In the vicinity of these structural features, the East Scotch Settlement Formation is further characterized by pervasive carbonatization that is commonly accompanied by base-metal-and gold-bearing silicification and high chromium-mica alteration zones.

Zircons from a felsic dome in the East Scotch Settlement Formation and from felsic schists in the Lawson Brook Formation yield $\mathrm{U}-\mathrm{Pb}$ dates of $493 \pm 2 \mathrm{Ma}$ and $497 \pm 10 \mathrm{Ma}$, respectively. Based on these dates and constituent lithologies, the Annidale Group is tentatively correlated with parts of the Cookson Group to the southwest.
\end{abstract}

La cartographie géologique et les datations $\mathrm{U}-\mathrm{Pb}$ sur les zircons ont mené à la découverte de roches volcaniques et sédimentaires distinctives, de l'Ordovicien inférieur, dans la région d'Annidale du sud du Nouveau-Brunswick. Ces roches sont comprises dans un Groupe nouvellement défini, nommé ici le Group d'Annidale, qui est divisé en trois unités possiblement bordées par des failles et dont les âges se recouvrent partiellement. Ces unités sont nommées, du nord au sud: la Formation de East Scotch Settlement, la Formation du Ruisseau Lawson et la séquence de Cannan Forks. La Formation de East Scotch Settlement contient une succession à pendage abrupt de volcanites mafiques et felsiques et un assemblage varié de roches sédimentaires clastiques et volcanogènes. La Formation du Ruisseau Lawson consiste en une succession à pendage faible ou modéré vers le nord dominée par les volcanites felsiques. La séquence de Cannan Forks, dont la majeure partie est une succession à pendage faible ou modéré vers le nord, est dominée par les roches sédimentaires clastiques. Structuralement, une bonne partie du Groupe d'Annidale est caractérisée par un cisaillement intense produit par de nombreuses failles verticales nord et nord-est et par des failles de chevauchement vers le sud et le nord. A proximité de ces failles, la Formation de East Scotch Settlement est caractérisée par une carbonatation intense qui est communément accompagnée par une silicification porteuse de métaux de base et d'or et de zones d'altération à mica chromifère.

Les zircons d'un dôme felsique dans la Formation de East Scotch Settlement et de schistes felsiques dans la Formation du Ruisseau Lawson ont donné des âges U-Pb de $493 \pm 2 \mathrm{Ma}$ et $497 \pm 10 \mathrm{Ma}$, respectivement. Sur la base de ces datations et de similarités lithologiques, le Groupe d'Annidale est tentativement corrélé avec des parties du Groupes de Cookson, situé au sud-ouest.

[Traduit par le journal]

\section{INTRODUCTION}

A belt of volcanic and sedimentary rocks located in the Annidale area of south-central New Brunswick (Fig. 1) is poorly exposed, unfossiliferous and contains lithologies similar to units of known Ordovician, Silurian and DevonoCarboniferous age. Therefore, previous investigators have assigned various Paleozoic ages to all or parts of the belt 


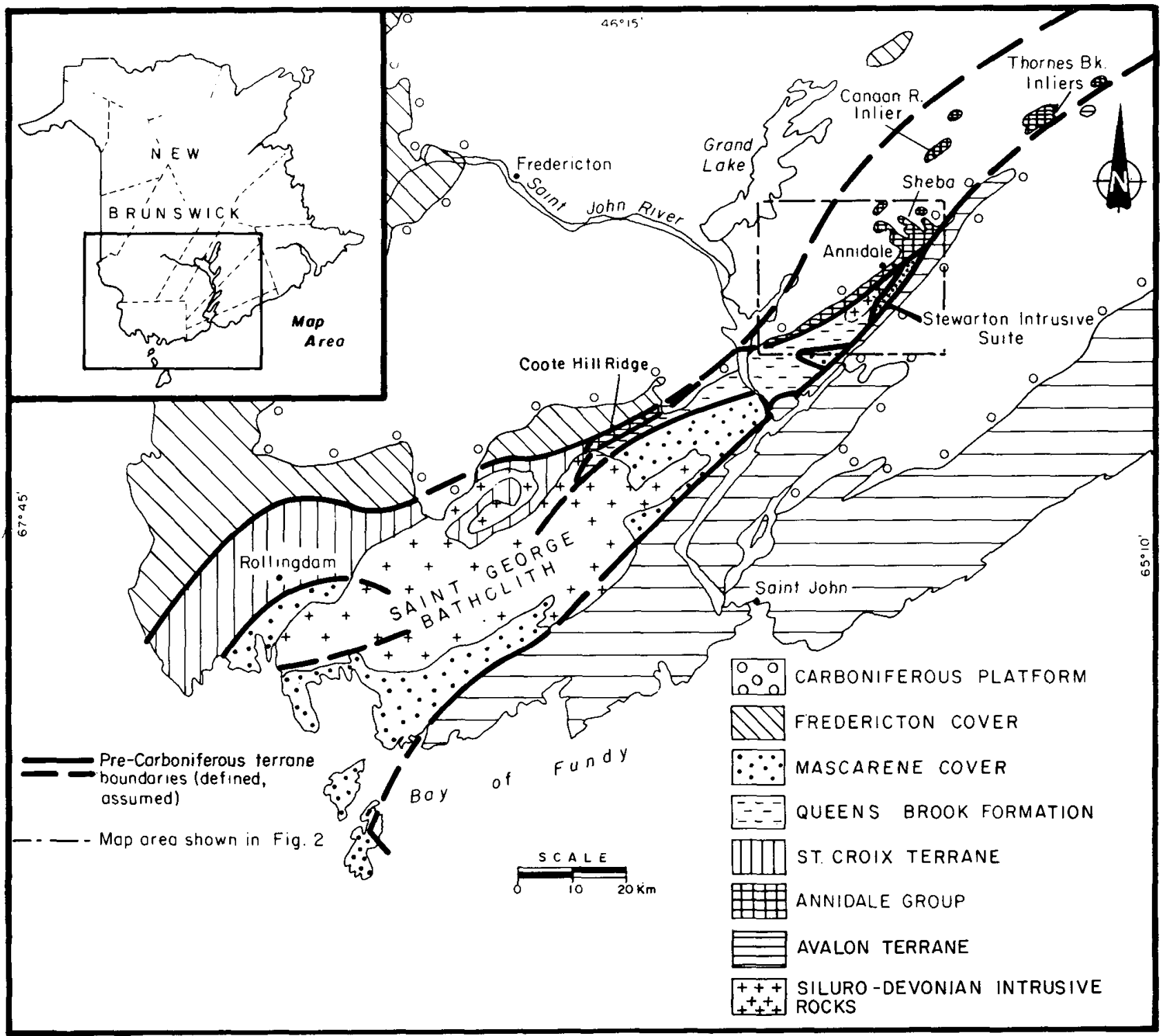

Fig. 1. Generalized geological map of southwestern New Brunswick showing distribution of major geological units.

(Alcock and MacKenzie, 1946; Hamilton, 1961; Ruitenberg, 1970; Potter et al., 1968; McCutcheon and Ruitenberg, 1987). Reconnaissance geological mapping conducted as part of a regional compilation and correlation project (McLeod et al., 1989), however, indicated that these rocks could be correlative with Lower to Middle Ordovician rocks in the Rollingdam area (Ruitenberg, 1967; Fyffe and Riva, 1990). Ordovician rocks in the Rollingdam and Annidale areas are similar in that they both include black carbonaceous shale, sulphide-rich fine-grained sedimentary rocks, mafic volcanic rocks and sequences containing thick-bedded feldspathic wackes interbedded with dark grey siltstone and shale. In the Annidale area, however, there is a much greater proportion of mafic volcanic rocks, abundant volcanogenic sedimentary rocks and voluminous felsic volcanic rocks. Structurally, the Ordovician rocks in the Rollingdam area are characterized by systematic polyphase deformation involving at least four phases of folding commonly with associated cleavages
(Ruitenberg, 1967; Fyffe, 1990a). In contrast, rocks in the Annidale area are typified by intense shearing and numerous faults which may have mostly obliterated evidence of possible earlier fold structures.

The purpose of this paper is to describe the stratigraphy and structure of volcanic-sedimentary rocks in the Annidale area, to present new U-Pb (zircon) dates from two felsic rocks in the area, and to suggest correlations with other units in southern New Brunswick. The radiometric dates provide, for the first time, age control for rocks in the Annidale area.

\section{Regional Geology}

The St. Croix Terrane (Fyffe and Fricker, 1987) of southern New Brunswick (Fig. 1) forms the northeastern part of the more extensive Cambro-Ordovician terrain or St. Croix belt of Ludman $(1978,1987)$. It consists predominantly of Ordovician sedimentary and minor mafic volcanic 
rocks that crop out in the Rollingdam area (Cookson Formation of Ruitenberg, 1967). The Cookson Formation has been elevated to group status (Ludman, 1987) and has been expanded in New Brunswick to include the Digdeguash Formation (Fyffe and Riva, 1990). Other revisions and their interpretations, which will not be reiterated, are contained in Ludman (1991a). To be consistent with the current New Brunswick terminology, the interpretation of Fyffe and Riva (1990) is followed here. In general, the surface exposure of the St. Croix Terrane lies north of the Upper Precambrian to Lower Paleozoic rocks of the Avalon Terrane and SiluroDevonian rocks of the Mascarene Cover Sequence, and south of Silurian rocks of the Fredericton Cover Sequence (Fyffe, 1990a; McLeod et al., 1990).

Relative to other major rock units, the volcanic-sedimentary sequence in the Annidale area spatially occupies a position that is comparable with that of the Cookson Group in the St. Croix Terrane. In the Annidale area, however, a belt of intensely deformed sedimentary and minor volcanic rocks assigned to the Queens Brook Formation (McCutcheon and Ruitenberg, 1987; modified by McLeod et al., 1991a) separates the volcanic and sedimentary rocks of the Annidale belt from the Avalon Terrane (Fig. 1). The terrane affiliation of the Queens Brook Formation is inconclusive. Lithologies in the formation are similar to those in both rocks of the Annidale area to the northwest and rocks correlated with the Cambrian (Avalon Terrane) to the southeast, but exhibits structures most similar to rocks in the Annidale area. McCutcheon and Ruitenberg (1987) suggested that contacts are gradational between the Queens Brook Formation and the overlying Silurian rocks of the Mascarene Cover Sequence, and between the Queens Brook Formation and rocks of the Annidale area. However, in this paper, due to the tectonized or unexposed nature of contacts and the absence of age control, the Queens Brook Formation is considered as a separate belt with unknown regional implications.

The southern boundary of the volcanic and sedimentary rocks in the Annidale area is the Falls Brook-Taylor Brook Fault (Fig. 2). The on-strike extension of this fault to the southwest, although sealed by the Saint George Batholith; is interpreted to mark the boundary between the St. Croix and Avalon terranes (Thomas and Willis, 1989; McLeod, 1990). The boundary between volcanic and sedimentary rocks of the Coote Hill area and the Fredericton Cover Sequence is clearly defined by a fault (McCutcheon and Ruitenberg, 1987) that also appears to strike into the Saint George Batholith (McLeod et al., 1991c). The northern boundary of the St. Croix Terrane along strike to the southwest, which was recently considered to be defined by the Basswood Ridge-Cox Brook-Pendar Brook Fault (Fyffe, 1990a), is actually partly unfaulted and conformable with Silurian rocks (Ruitenberg, 1967; Fyffe, 1991). The subsurface extension of the rocks in the Annidale area has been traced northeastward to Prince Edward Island beneath Carboniferous cover utilizing borehole, magnetic and seismic data (Fyffe, 1990b).

The St. Croix Terrane, the Mascarene and Fredericton cover sequences, and possible correlative units of the Queens
Brook Formation have been traced farther southwest into Maine. The reader is referred to Berry and Osberg (1989) and Ludman (1991b) for detailed descriptions of these units, possible regional implications, and additional reference material.

\section{STRATIGRAPHY}

The Annidale Group is a new name assigned to sequences of volcanic and sedimentary rocks that crop out in the Annidale area from Kierstead Mountain in the northeast to Shannon in the southwest (Fig. 2). Also included in the group are sedimentary sequences that occur in inliers surrounded by Carboniferous rocks in the Thornes Brook-Canaan River area and a mainly sedimentary sequence in the Coote Hill Ridge area (Fig. 1).

In the Annidale area, the group is divisible into three main sequences distinguished by lithology and structure (Fig. 2). The southern and central sequences are the focus of this study. The southern sequence, here termed the East Scotch Settlement Formation, consists of steeply dipping mafic and felsic volcanic rocks intercalated with a variety of volcanogenic and clastic sedimentary rocks. This formation, particularly the mafic volcanic rocks, is commonly cut by zones of extensive alteration characterized by the presence of carbonate, silica and chromium-rich micas in which numerous significant gold and base metal occurrences have been identified. The central sequence, here termed the Lawson Brook Formation, is composed of felsic volcanic rocks, felsic mica schists and minor mafic volcanic rocks that dip at shallow to moderate angles toward the northwest. The northern unit, the Canaan Forks sequence, has not yet been assigned formation status. It contains clastic sedimentary rocks that mostly dip at moderate to steep angles to the northwest.

The Annidale Group ranges in age from Lower Ordovician (the East Scotch Settlement and Lawson Brook formations) to possibly Lower Silurian (the Canaan Forks sequence in the Thornes Brook and Coote Hill Ridge areas), based on radiometric dating described below and regional correlations. Contacts between and within major units in the group are obscured by younger cover rocks, are not exposed or are faulted, making thickness estimates difficult. The overall thickness is in the order of $4000 \mathrm{~m}$, ignoring the possibility of stratigraphic repetition by folding. The entire group has been subjected to chlorite-grade and, locally, biotite-grade regional metamorphism.

\section{East Scotch Settlement Formation}

The East Scotch Settlement Formation crops out in a narrow, northeast-trending belt $(3 \times 30 \mathrm{~km})$ from Shannon to Kierstead Mountain, and is bounded by the Taylor Brook Fault and Carboniferous cover rocks to the southeast and northwest, respectively (Figs. 1,2). Due to the paucity of outcrops and numerous faults, the detailed internal stratigraphy of this formation is difficult to ascertain. Examination of available outcrops, recently excavated exploration trenches, 


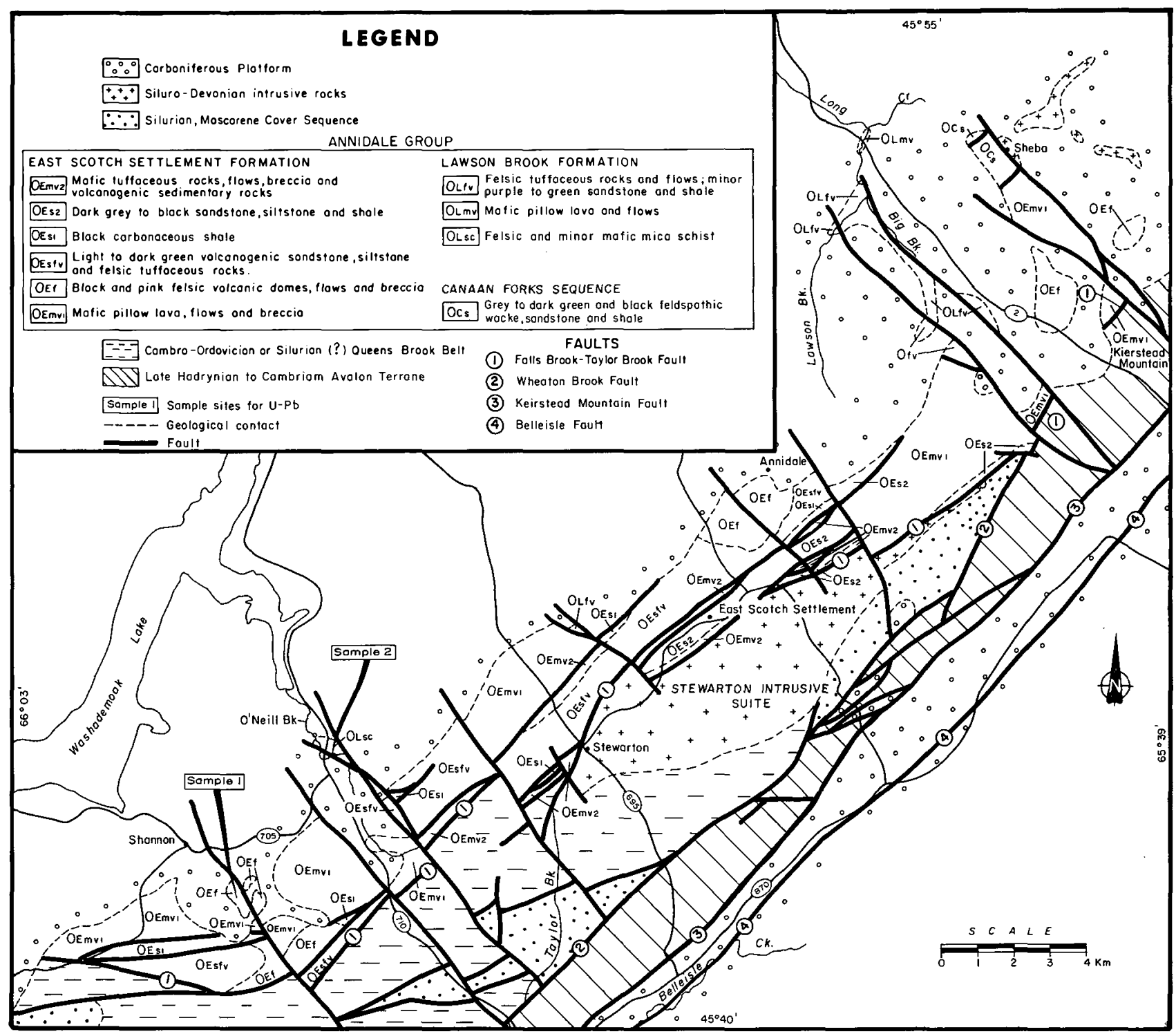

Fig. 2. Geological map of the Annidale Group in the Annidale area, showing locations of sample sites for U-Pb dates.

and diamond drill cores, however, indicates that the total thickness is at least $2000 \mathrm{~m}$ and that the formation youngs southward. Typical exposures of the formation occur along the secondary road that joins Highway 895 at Stewarton and in outcrops near the same road in the vicinity of East Scotch Settlement. Good sections are afforded by diamond drill core (e.g., BH 83901 and BF89-1, 2 and 3) stored at the New Brunswick Department of Natural Resources and Energy core facility in Sussex, New Brunswick.

The oldest exposed rocks in the East Scotch Settlement Formation are variably deformed pillow lava, mafic flows and, less commonly, mafic breccia. These rocks are overlain by a sheared unit consisting of poorly sorted and thin-bedded, light to dark green volcaniclastic sandstone and siltstone, interbedded with very fine-grained felsic tuffaceous rocks. Most of the volcanic debris in the sandstone is felsic but, locally, mafic debris predominates.

Ovate bodies of felsic rocks that represent intrusive domes are spatially associated with these rocks. One such body near Shannon, partially concealed by Carboniferous rocks, consists of fractured and altered, but otherwise undeformed, slightly porphyritic black felsite. Intense silicification and bleaching of the felsite emanates from profuse and irregular stockwork-like fractures filled with hematite and chlorite. Volcanic breccias composed entirely of black felsite fragments and felsic flows are associated with the black felsite at this locality. Another body near Annidale, referred to as a possible volcanic neck by Hamilton (1961), is about 2 $\mathrm{km}$ in diameter and consists of massive, slightly porphyritic pink to purple felsite, breccia and minor microgranite. Isolated outcrops and float composed of massive and sheared felsic tuffaceous rocks and flows occur peripheral to this body. In the Kierstead Mountain area, isolated outcrops of massive rhyolite, felsic breccia and microgranite surrounded by Carboniferous cover rocks may represent other partially buried felsic domes. 
The youngest exposed rocks in the East Scotch Settlement Formation consist of alternating units containing irregularly folded and sheared, dark grey to black, thin-bedded sandstone, siltstone and shale, intercalated with variably deformed mafic tuffaceous rocks, flows, breccias and volcanogenic sedimentary rocks. Although proportions vary at a given locality, sedimentary rocks are more abundant than volcanic rocks. Mafic volcanic debris predominates in the volcanogenic sedimentary rocks. Where thicknesses can be ascertained, individual sedimentary and volcanic units vary in thickness from about $1 \mathrm{~m}$ to several tens of meters. Contacts between these units are invariably sheared.

The units at the top of the sequence, particularly the mafic volcanic and volcanogenic sedimentary rocks, are notably high in Fe-Ti oxide content (now leucoxene), sulphiderich and commonly intensely altered. Carbonate, silica and/ or chromium-rich muscovite alteration overprints the lower greenschist metamorphic assemblage and, in places, nearly obliterates the regional metamorphic mineralogy. Gold and/ or base metals are associated with the alteration zones. Ultramafic rocks may also occur in the East Scotch Settlement Formation, even though no indisputable ultramafic rocks have been found in outcrop. Their presence is suggested by the occurrence of discrete, linear zones with high chromium, nickel and magnesium rocks south of Annidale, which is indicated by detailed soil sampling surveys in that area (Woods, 1990), isolated outcrops of highly serpentinized rock, and the presence of extensive (up to $100 \mathrm{~m}$ wide) chromium-rich mica alteration zones. These features could reflect the presence of either tectonic slivers of ophiolitic rocks or ultramafic intrusions near surface.

Black carbonaceous and, locally, highly pyritiferous shale occurs sporadically throughout the formation as thin intercalations a few tens of centimeters thick or as larger units tens of meters thick. This rock type is invariably intensely deformed and occurs only sparsely at surface. Where exposed, these shales commonly host gold- and/or base-metal enriched gossan zones.

\section{Lawson Brook Formation}

Rocks assigned to the Lawson Brook Formation form a narrow belt (about $3 \times 20 \mathrm{~km}$ ) at least $500 \mathrm{~m}$ thick that rims the East Scotch Settlement Formation to the northwest and north and also unconformably underlies Carboniferous cover rocks (Fig. 2). The discontinuous nature of exposures and gentle dips preclude accurate thickness estimates. Contact relationships with other rocks in the Annidale Group are generally unknown but are assumed to be faulted. The best exposures are afforded by an along-strike section along Lawson Brook west from its confluence with Big Brook (Fig. 2).

The Lawson Brook Formation is dominated by mediumto thick-bedded felsic volcanic rocks, which include sheared, pink to grey felsic tuffaceous rocks and intensely fractured but unsheared felsic flows. Minor amounts of sheared, purple to green, siltstone and shale and altered granitoid rocks are also present. Deformation has obscured internal primary structures in most of the stratified rock, but flow banding and delicate volcanic textures such as spherulites are preserved at some localities. Thicker, slightly porphyritic flows are commonly fractured and altered, and consequently resemble the felsites in the East Scotch Settlement Formation. Although not in direct contact with the felsic rocks, sheared flat-lying pillow lavas that occur in an inlier on Big Brook are also assigned to the Lawson Brook Formation. Very minor amounts of sheared black siltstone and green sandstone are in faulted contact with volcanic rocks on the west end of Lawson Brook, immediately west of the fault that cuts the brook. These rocks may be part of the Canaan Forks sequence described below.

Felsic mica schist and minor amounts of more mafic schist, which occur in the inlier on O'Neill Brook $5 \mathrm{~km}$ northeast of Shannon, dip shallowly to the northwest on strike with felsic rocks of the Lawson Brook Formation. The felsic mica schist is poorly bedded, is highly sheared and contains abundant metamorphic muscovite and a few percent biotite, together totalling up to $35 \%$ of the schist at some localities. The micas occur as individual grains up to $0.5 \mathrm{~mm}$ long and in aggregates up to $0.5 \mathrm{~cm}$ long parallel to structural fabrics. The remainder of the felsic rocks consist of more coarsely crystalline unaltered plagioclase that occurs as individual crystals or as aggregates up to $2 \mathrm{~cm}$ in diameter. These rocks contain a finer-grained completely recrystallized matrix composed mostly of quartz and much less muscovite. The more mafic schist is mostly composed of muscovite, finergrained masses of epidote and carbonate, and minor amounts of chlorite and biotite.

\section{Canaan Forks sequence}

The northernmost units of the Annidale Group crop out over a $10 \times 30 \mathrm{~km}$ area north and northeast of Annidale in scattered inliers surrounded by Carboniferous cover rocks, and in a narrow fault block in the Coote Hill Ridge area (Fig. 1). All contain clastic sedimentary rocks that dip shallowly to moderately and, locally, steeply to the northwest, and all exhibit variable intensity of deformation characteristic of the area. Reconnaissance mapping indicates that there are three main types of sequences exposed in the Thornes Brook, Sheba and Canaan River inliers. The Thornes Brook inliers contain medium- to thick-bedded and poorly sorted, grey to dark green feldspathic wackes interstratified with thinly bedded, dark grey to black siltstone, sandstone and shale. The section in this inlier is at least $1500 \mathrm{~m}$ thick. Identical lithologies comprise about half of the fault block in the Coote Hill Ridge area. The remainder of the fault block contains abundant black carbonaceous and, locally, manganiferous shale and minor highly altered mafic volcanic rocks. Surface exposures in the inlier at Sheba contain lithologies similar to those in the Thornes Brook inliers but the thicker sandstone beds are less feldspathic and the intercalated siltstone and shale units are more massive and, locally, highly pyritiferous. Preliminary examination of drill core from the Sheba 
area drilled by exploration companies (e.g., Roberts and Prince, 1987) indicated that rhythmic, thin-bedded, light green sandstone and siltstone also occur in this inlier.

The inlier on the Canaan River contains lithologies unlike those in other inliers or in the remainder of the Annidale Group, and may not be part of it. It contains light green to grey shale, siltstone and minor amounts of thinbedded, slightly calcareous sandstone.

\section{Structure}

Many rocks in the Annidale Group, especially clastic sedimentary and volcanogenic rocks, exhibit a single well developed cleavage subparallel to bedding. Near faults and shear zones, this cleavage is locally sheared and refolded and commonly irregularly contorted. These features are exemplified in trenches at the Dick Mine just south of Annidale (Ruitenberg, 1970). The more homogeneous rock types, such as pillow lavas, mafic flows and felsic domes, exhibit little or no penetrative deformation but do contain narrow shear zones and are frequently intensely fractured. This contrast in structural characteristics is important in localizing metalrich veining and is illustrated in exploration trenches and diamond drill holes in the upper part of the East Scotch Settlement Formation north of the Stewarton Intrusive Suite. In this area, intensely sheared and contorted siltstone and sandstone, otherwise relatively unaltered, are interbedded with brittly fractured mafic volcanic rocks that are permeated by silica, carbonate and sulphides, as previously described.

Numerous vertical northeast- and northwest-trending faults and shear zones, and southward- and northward-directed thrust faults, occur in the Annidale Group and are particularly prevalent in the East Scotch Settlement and Lawson Brook formations. The vertical northeast-trending faults and shear zones are subparallel to the penetrative fabric in the East Scotch Settlement Formation and commonly bound mappable units in the formation. The magnitude and direction of displacement on these faults, however, are unknown. Many of the quartz-carbonate and chromium mica alteration zones with associated base metal sulphides and gold occur in and/or near these structures.

Episodes of southward- and northward-directed thrusting distinct from the northeast-trending faulting are evident in the Annidale Group. Southward-vergent faults are prevalent in the northern part of the group, whereas northwardvergent faults occur in the south. Southward-verging, shallowly plunging folds that form within shear zones and beneath shallowly dipping faults occur in the Lawson Brook Formation and in the Canaan Forks sequence. These faults and shear zones truncate the shallowly to moderately northward-dipping penetrative fabrics at a shallow angle and commonly produce secondary, north-dipping shear zones and/or a closely spaced crenulation cleavage. Northwarddirected thrusts with northward-verging, shallowly plunging folds occur at the southern boundary along the Taylor Brook Fault and within the East Scotch Settlement Formation.
These faults appear to both predate and postdate the steeply dipping penetrative fabric.

Offsets in stratigraphy indicate that movement along the northwest-trending faults (Fig. 2) was relatively minor (in the order of a few kilometers) and that sinistral, dextral and vertical displacements occurred. Open, northwest plunging chevron folds, as described by McCutcheon and Ruitenberg (1987), are associated with those faults.

The relative timing of faulting events is approximated by crosscutting relationships observed in the field and by map patterns. The vertical northeast-trending faults both pre- and postdate the northward-directed thrusts, but the timing of these faults relative to the southward-directed thrust is unknown. The northwest-trending faults offset all other structures. The absolute timing is poorly constrained, but, by comparison with major structures to the south (McCutcheon and Robinson, 1987), the northeast-trending faults are, most likely, mainly Acadian structures (Siluro-Devonian). In New Brunswick, all the major movement along northeast-trending faults effectively ceased prior to emplacement of the Late Devonian Mount Douglas Granite (McLeod, 1990). In Maine, recent radiometric dates indicate that the latest major movement on similar faults is Lower Silurian or older (A. Ludman, personal communication, 1992). Minor reactivation of the faults in the Annidale area during the Carboniferous is indicated by offsets of Namurian and, possibly, Westphalian strata by the vertical northeast- and northwest-trending faults.

Similar faulting patterns are documented elsewhere in southern New Brunswick and eastern Maine. Particularly relevant are the major faults immediately south of the Annidale Group that affect Avalon Terrane and Mascarene cover rocks. These faults dip to the south and are considered to be high angle reverse or thrust faults (McCutcheon, 1981). In the Rollingdam area, southward-vergent structures predate northward-directed thrusts in the St. Croix Terrane (Ruitenberg, 1967). Farther along strike in Maine, St. Croix Terrane and Fredericton cover rocks are affected by similarly oriented thrusts and high-angle reverse faults followed by offsets along northeast- and northwest-trending strike-slip faults (Ludman, 1991b). The distribution of thrusts and highangle reverse faults in the Annidale area suggests that the Annidale Group represents remnants of an axial belt affected by southward-directed tectonic transportation of Fredericton cover rocks and northward-directed tectonic transport of Avalon Terrane rocks.

\section{Geochronology}

Zircons were concentrated from 20 to $40 \mathrm{~kg}$ of rock using conventional techniques, and final purification was achieved by hand-picking under a binocular microscope. Samples were prepared and analysed according to the methods described by Krogh $(1973,1982)$. Data regressions were calculated according to Davis (1982), and errors are quoted at the 95\% (2 sigma) confidence level. The $U$ decay constants used are those of Jaffey et al. (1971). 
Sample 1 (field number H12-13-89) is a massive black felsite from the East Scotch Settlement Formation. It provided a relatively low yield of small, euhedral 2:1 prisms typical of rhyolitic lavas. Crack-free grains suitable for precise dating were selected grain by grain and classified into three fractions according to the abundance of minute imperfections visible after abrasion. Every effort was made to avoid inherited components by selecting only grains and grain fragments with exterior prismatic surfaces. Since the yield was low, the procedure of using only grains from the non-magnetic fraction was abandoned and all fractions nonmagnetic at $5^{\circ}$ tilt (on a Frantz magnetic separator at full magnetic field) were used as starting material.

The results (Table 1, Fig. 3a) indicate that inherited components were successfully avoided, as all three analyses agree within the measurement error with $\mathrm{Pb} / \mathrm{Pb}$ ages of 494 , 494 and $492 \mathrm{Ma}$. In addition, recent lead-loss was, to a large degree, avoided, as the data plot only $0.2,0.6$ and $1.3 \%$ below the concordia curve. With two points overlapping the curve, an age of $493 \pm 2 \mathrm{Ma}$ can be derived from the mean $\mathrm{Pb} / \mathrm{Pb}$ ages obtained. This interpretation assumes that any minor leadloss occurred in the recent geological past. If, as noted below, the time of lead-loss was as old as about $330 \mathrm{Ma}$, then an age of $500 \mathrm{Ma}$ would be obtained from these data.

Sample 2 (field number H12-07-89) is from highly deformed, coarsely crystalline and low mica felsic schist tentatively assigned to the Lawson Brook Formation. It contained a small amount of small, sharp-faceted, zircon prisms typical of a rhyolitic protolith. Three fractions of high-quality, crackfree zircon grains were selected. Two fractions differed in the abundance of rare micro-cracks visible after abrasion (2-1 and 2-2, Table 1, Fig. 3b), while a third fraction of euhedral fragments (2-3, Fig. 3b), was analysed without abrasion to give a more discordant point useful for projecting other data up to the concordia curve.

The results show that inheritance was probably avoided in two of the three fractions (2-2 and 2-3, Fig. 3b), whereas the third fraction (2-1) must contain a small amount of inherited zircons with a mean age of about $940 \mathrm{Ma}$. In this case, more that one age interpretation is possible, based mainly on analysis $2-2$, which lies only $1 \%$ below the curve. If we project through analyses 2-1 and 2-2, a minimum time of extrusion is established at $488 \mathrm{Ma}$, whereas a projection through analyses 2-2 and 2-3 gives a maximum age of emplacement at $507 \pm 2 \mathrm{Ma}$. These options could be combined to give an age of $497 \pm 10 \mathrm{Ma}$. A more precise age will require further analyses. The first interpretation implies that a very small, but significant amount of inheritance is present in analysis $2-2$, and the other interpretation implies that this analysis is inheritance-free. In the latter case, the line would project to a time of lead-loss $330 \mathrm{Ma}$ ago, which is possible, given the known geological history of the region. We should point out that all of the zircons are small, do not appear to have cores, and cannot be precisely analysed unless 5 to 10 grains are combined. In addition, their low lead content places them well below the detection level of ion microprobe techniques.

\section{Correlations}

The U-Pb dates and lithological similarities between the Annidale and Cookson groups permit the tentative regional correlations illustrated in Figure 4. Two possible stratigraphic positions for the Queens Brook Formation are also included in this figure. It is notable that due to structural complexities and Carboniferous cover rocks, relationships between the three major sequences in the Annidale Group and between the Annidale and Cookson groups are not exposed and are assumed to be tectonic. The presence of lithologically and chemically (unpublished information) similar felsic and mafic volcanic rocks in the East Scotch Settlement and Lawson Brook formations, combined with their similar $\mathrm{U}-\mathrm{Pb}$ dates, establish the correlation of these two units. The presence of black carbonaceous shale and similar mafic volcanic rocks in the East Scotch Settlement Formation and the Tremadocian Calais Formation (Cookson Group; Fyffe and Riva, 1990) suggest a possible correlation. In contrast with the Annidale Group, however, volcanic rocks are relatively rare and the typical black felsite is absent from the Cookson Group in New Brunswick. In Maine, however, very minor amounts of dark grey felsic volcanic rocks occur in the Kendall Mountain Formation of the Cookson Group (Ludman, 1987).

Lithologies of the Canaan Forks sequence exposed in the inliers around Thornes Brook and in part of the fault block in the Coote Hill Ridge area (Fig. 1) are similar to the Digdeguash Formation of Ruitenberg (1967) and Fyffe and Riva (1990). Those in the inlier at Sheba and in the remainder of the fault block in the Coote Hill Ridge area (Fig. 1) resemble the Woodland Formation and, in some aspects the Calais Formation, respectively. These formations comprise part of the Cookson Group as defined by Fyffe and Riva (1990). Therefore, most of the Canaan Forks sequence probably represents facies-equivalent rocks to the Cookson Group. Detailed mapping of this sequence is required to determine their relationship.

The clastic sedimentary rocks in the inlier on the Canaan River do not appear to have direct correlatives in the Cookson Group but resemble sections of thinly bedded shale and siltstone in the Queens Brook Formation south of the Taylor Brook Fault.

\section{Discussion}

Some aspects of the stratigraphy, structure, geochronology, and regional implications warrant additional discussion and speculation. The schists assigned to the Lawson Brook Formation are unlike any others known in this region of New Brunswick and their placement in the Lawson Brook Formation is equivocal. The correlation is based on their location, relict bedding(?) styles, their predominantly felsic compositions and the nature of their zircon. We envisage the schists to be retrograded and completely recrystallized felsic tuffaceous rocks and felsic flows of the Lawson Brook Formation, emplaced in their present position by faulting (thrust- 
Table 1. U-Pb isotopic data for zircons.

\begin{tabular}{|c|c|c|c|c|c|c|c|c|c|c|}
\hline $\begin{array}{l}\text { Description } \\
\text { fraction no. }\end{array}$ & $\begin{array}{l}\text { Weight } \\
\text { (mg) }\end{array}$ & $\underset{(p p m)}{U}$ & $\begin{array}{c}\mathrm{Pb} \\
(\mathrm{ppm})\end{array}$ & $\begin{array}{r}\mathrm{Pb}^{\mathrm{a}} \\
(\mathrm{pg})\end{array}$ & $\begin{array}{l}\text { Atomic Ratios } \\
{ }^{206} \mathrm{~Pb} /{ }^{204} \mathrm{~Pb}^{\mathrm{b}}\end{array}$ & ${ }^{208} \mathrm{~Pb}^{\mathrm{d}}{ }^{204} \mathrm{~Pb}^{\mathrm{b}}$ & ${ }^{206} \mathrm{~Pb} /{ }^{238} \mathrm{U}^{\mathrm{b}}$ & ${ }^{207} \mathrm{~Pb} /{ }^{235} \mathrm{U}^{\mathrm{b}}$ & ${ }^{207} \mathrm{~Pb} / 206 \mathrm{~Pb}$ & ${ }^{207} \mathrm{~Pb} /{ }^{206} \mathrm{~Pb}$ \\
\hline & 0.048 & 283 & 25 & 25 & 2720 & 0.2386 & 0.07913 & 0.6220 & 0.05701 & 492 \\
\hline $\begin{array}{l}\text { euh } \\
1-2 . \\
\text { N3',M3,M5., }\end{array}$ & 0.072 & 281 & 25 & 47 & 2159 & 0.2427 & 0.07857 & 0.6182 & 0.05706 & 494 \\
\hline $\begin{array}{l}\text { euh } \\
1-3 . \\
\text { N3 } 3^{\circ}, 3^{\circ} \text {,euh }\end{array}$ & 0.060 & 198 & 17 & 5 & 13021 & 0.2202 & 0.07921 & 0.6234 & 0.05708 & 494.4 \\
\hline $\begin{array}{l}2-1 . \\
\text { No ,cl,euh }\end{array}$ & 0.036 & 183 & 17 & 3 & 13462 & 0.2372 & 0.08172 & 0.6528 & 0.05793 & 527 \\
\hline $\begin{array}{l}2-2 \text {. } \\
\text { N0, cl,euh }\end{array}$ & 0.046 & 204 & 18 & 5 & 9501 & 0.2511 & 0.07936 & 0.6254 & 0.05715 & 497.3 \\
\hline $\begin{array}{l}2-3 \text {. } \\
\text { M0 ,euh,tip, } \\
\text { un-abr }\end{array}$ & 0.181 & 223 & 19 & 48 & 4167 & 0.2335 & 0.07757 & 0.6093 & 0.05696 & 490 \\
\hline
\end{tabular}

Notes: All fractions abraded unless noted; N3 ${ }^{\circ} \mathrm{M}^{*}=$ non-magnetic, magnetic @ $3^{\circ}$ on the Frantz; $c l=c l e a r$, euh $=$ euhedral; $a=b l a n k+$ zircon common Pb and corrected for common $\mathrm{Pb}$ in ${ }^{205} \mathrm{~Pb}$ spike; $\mathrm{b}=$ corrected for fractionation, blank, common $\mathrm{Pb}$, common $\mathrm{Pb}$ isotopic composition calculated using $\mathrm{Stacy}$ and $\mathrm{Kramers}$ (1975); $c=c o r r e c t e d$ for fractionation and blank, $U$ blank $=0.5 \mathrm{Pg}, \mathrm{Pb}$ blank $\leq 8.2 \mathrm{Pg}, \mathrm{Pb}$ and $U$ fractionation correction $=0.13 \% / \mathrm{amu} ; 20 \mathrm{errors}$ for $\mathrm{Pb} / \mathrm{U}$ and $207 \mathrm{~Pb} / 206 \mathrm{~Pb}$ ratios $=0.25 \%$ and $0.05 \%$, respectively: ${ }^{238} \mathrm{U}$ decay constant $=0.15513 \times 10^{-9} / \mathrm{Yr}_{\mathrm{r}},{ }^{235} \mathrm{U}$ decay constant $=0.98485 \times 10^{-9} / \mathrm{Yr}_{\mathrm{r}}{ }^{238} \mathrm{U} /{ }^{235} \mathrm{U}=137.88$.

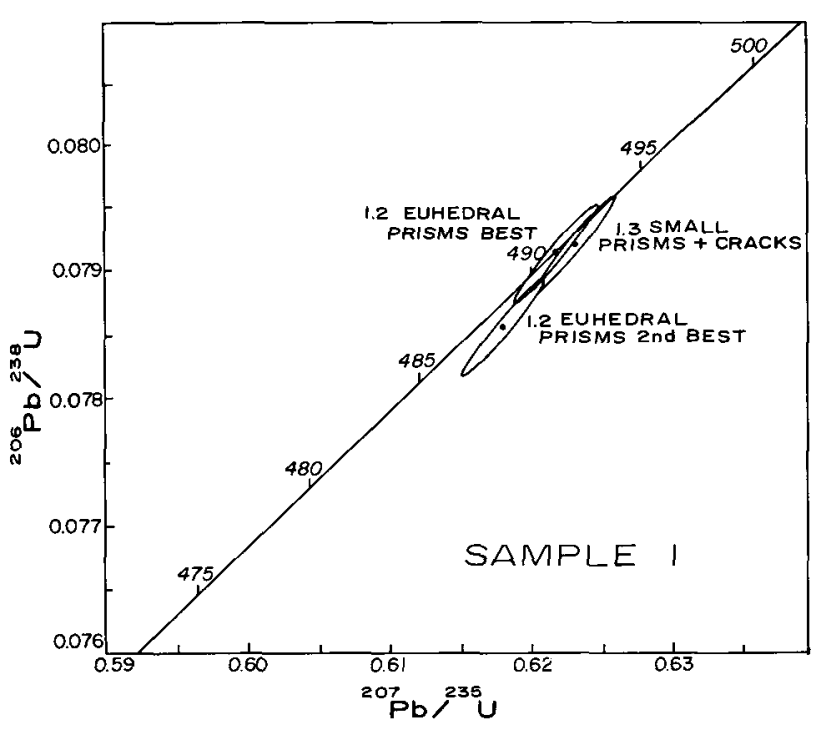

(a)

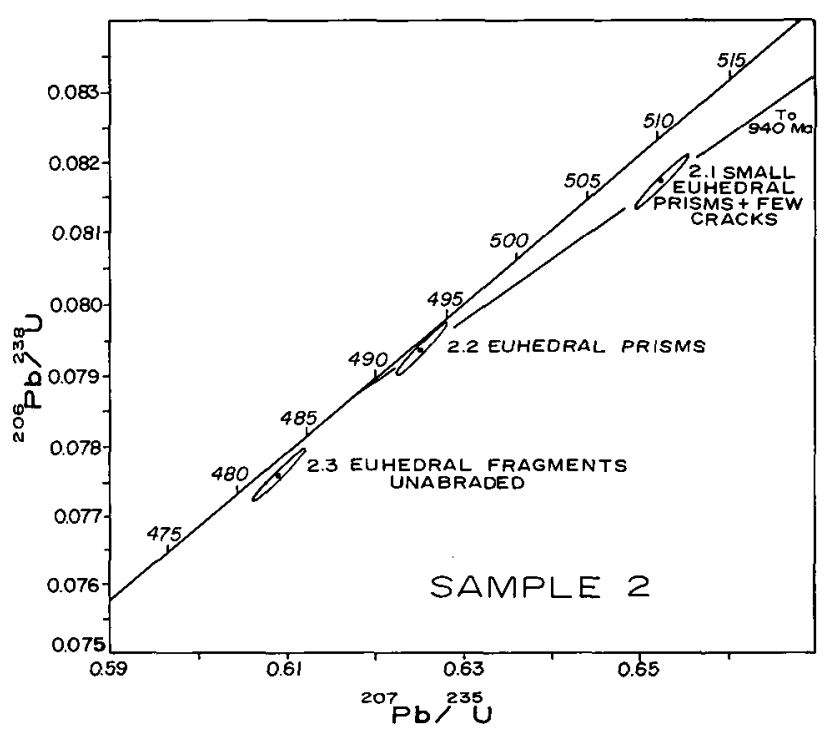

(b)

Fig. 3. U-Pb concordia diagrams for zircons from (a) sample 1 massive felsite south of Shannon and (b) sample 2 from felsic mica schist on O'Neill Brook.

ing?). We consider the dated zircons to be primary igneous minerals. An alternative explanation of the protolith, as could be indicated by abundance of mica and, locally, mica + epidote, is that the schist represents intensely sheared and recrystallized clastic and/or volcaniclastic rocks of appropriate compositions. In this case, the zircon could be detrital and not reflect the age of crystallization. The former explanation appears more likely since the samples dated were selected from a coarsely crystalline layer (flow?) that contains only minor mica and relatively pristine euhedral zircons that show no signs of sedimentary transport.

It is emphasized that correlation of the major units of the
Annidale Group, particularly the East Scotch Settlement and Lawson Brook formations, with the Cookson Group (St. Croix Terrane) is considered tentative. If the East Scotch Settlement and Lawson Brook formations are not direct correlatives of the Cookson Group, then these parts of the Annidale Group could represent remnants of a volcanicsedimentary belt that developed between the St. Croix and Avalon terranes during the Lower Ordovician. In this case, the Ordovician clastic rocks of the St. Croix Terrane and the Cambro-Ordovician clastic sedimentary rocks of the Avalon Terrane may have been deposited in separate basins flanking the Annidale volcanic-sedimentary belt to the northwest and 


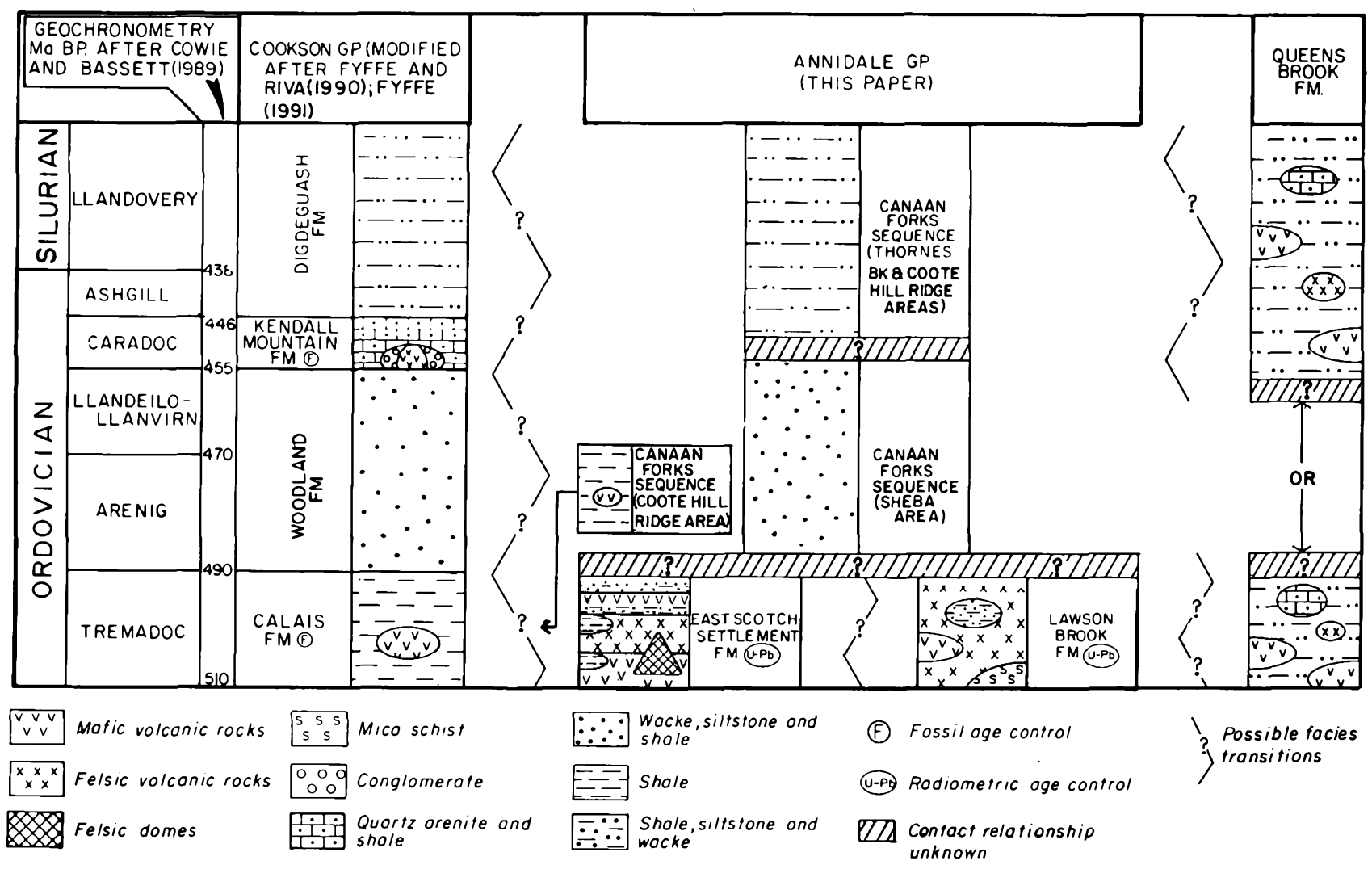

Fig. 4. Chart showing tentative correlations of the Annidale Group with the Cookson Group.

southeast, respectively. The Canaan Forks sequence most closely resembles formations in the Cookson Group but detailed work is required to confirm their correlation. Rocks exposed in the Canaan River inlier are lithologically most similar to the Queens Brook Formation and are, therefore, clearly anomalous. If this correlation is correct, the Queens Brook Formation would be more closely associated with the Annidale Group than with the Avalon Terrane to the south.

Structures within and bounding the Annidale Group reflect the complexity of juxtaposition (accretion?) of major lithotectonic belts or terranes and cover sequences in southen New Brunswick. The southward-directed thrusts, by comparison with the St. Croix Terrane in Maine (Ludman, 1991b), likely represent faults related to transportation of Fredericton cover rocks over the Annidale Group. The northward-directed thrusts may be a manifestation of faults related to the docking of the Avalon Terrane from the south which began during late Silurian time (Fyffe and Fricker, 1987). In more general terms, it has been shown that southward-directed thrusts are typically early structures (Late Ordovician to Early Silurian) that occur throughout the northern Appalachians and are generally attributed to major tectonic events related to closure of the Iapetus Ocean to the north (van de Pluijm and van Staal, 1988). Northward-directed thrust and high-angle reverse faults are widespread and are typically late, post-Early Silurian structures in the northern Appalachians (van de Pluijm and van Staal, 1988). In southern New Brunswick these faults are related to tectonic thickening during the Acadian Orogeny (McCutcheon and Robinson,
1987; Ruitenberg et al., 1990). Evidence in Maine, however, indicates that major movements on at least some of the northward-directed thrusts, as well as the southward-directed thrusts, occurred during or before early Silurian time (A. Ludman, personal communication, 1992). Although the amount and direction of displacement along the vertical northeast-trending faults in the Annidale area is unknown, comparisons with similarly oriented major faults and shear zones to the south (e.g., Leger and Williams, 1986; Doig et al., 1990) indicate that the Annidale faults may also represent part of the major tectonic regime related to accretion of the Avalon Terrane to North America.

Based on preliminary chemistry, McLeod et al. (1991b) tentatively suggested that volcanic-sedimentary rocks in the Annidale Group represent the vestiges (including volcanic rocks with MORB and back-arc signatures) of an accreted island-arc sequence. This suggestion would be reinforced if correlations with the Cookson Group are correct, as tholeiitic basalts of the Calais Formation were also related to rifting in a back-arc ensialic environment (Fyffe et al., 1988, 1990). The presence of voluminous felsic volcanic rocks in the Annidale Group indicates the involvement of a substantial crustal component (arc or continental?) in the volcanism of this area. The Annidale Group could represent one of many arcs that developed near the southern margin of the Iapetus Ocean. This interpretation is supported by workers in Newfoundland (e.g., Dunning et al., 1991) who have established the presence of at least one, and consider the possibly of several, Lower Paleozoic arcs and back-arc basins marginal 
to the Iapetus Ocean. As in Newfoundland, the development of the southeastern side of Iapetus in New Brunswick may have been more complex than previously suggested (e.g., Fyffe et al., 1990).

The nature of the basement to the Annidale Group is unresolved (see discussion in Fyffe et al., 1991). If it is assumed that the volcanic-sedimentary rocks in the Annidale Group developed on sialic crust, then two types of basement are most likely: (1) an older arc like the Cambrian arc in Newfoundland (Dunning et al., 1991) or (2) Avalon crust. Apparent inheritance in the zircons of sample 2, which provides a possible age of source rocks in the vicinity of 1000 $\mathrm{Ma}$, favors the latter possibility because rocks of the this age may occur in the Avalon Terrane (Nance, 1987).

\section{Conclusions}

This work establishes the Annidale Group as a distinct, mainly Lower Ordovician unit unique in southern New Brunswick. The group is subdivided into three main sequences that are tentatively correlated with formations in the Cookson Group (St. Croix Terrane) to the southwest. The East Scotch Settlement and Lawson Brook formations, which yield U-Pb dates of $493 \pm 2 \mathrm{Ma}$ and $497 \pm 10 \mathrm{Ma}$, respectively, are the same age as and have some lithological similarities to the Calais Formation. Most of the Canaan Forks sequence of the Annidale Group is lithologically similar to the Digdeguash and possibly the Woodland formations.

The Annidale Group is characterized by numerous faults that reflect the complexity of tectonic (accretionary?) events associated with final closure of the Iapetus Ocean and the onset of the Acadian Orogeny (southward- and northwarddirected thrusts). Vertical northeast-trending faults of unknown magnitude and minor vertical northwest-trending faults further complicate the geology and hinder mapping and correlation of units locally and regionally.

It is suggested that the magmatism represented in the Annidale Group may be indicative of arc development close to or on Avalonian basement near the southeastern margin of the Iapetus Ocean. The role played by this arc in the development and distribution of the Iapetus Ocean, however, is unclear and is the subject of continuing research.

\section{Acknowledgements}

This project was funded jointly by the Canada-New Brunswick Cooperative Agreement on Mineral Development 1990-1995 and the New Brunswick Department of Natural Resources. The authors would like to thank Brian O'Brien and Allan Ludman (reviewers), and Sandra Barr (editor) for their constructive and thoughtful comments. Susan Johnson and Leslie Fyffe provided valuable advice and useful discussions both in and out of the field, and were instrumental in developing the concepts presented. The staff of the Geological Surveys Branch in Sussex, New Brunswick, and the geochronology laboratory of the Royal Ontario Museum in
Toronto, Ontario, are thanked for technical and logistical support. The ROM laboratory is supported by NSERC Operating and Infrastructure grants to T. Krogh.

Alcock, F.J. and MacKenzie, G.S. 1946. Sussex map sheet, Kings and Queens counties, New Brunswick. Geological Survey of Canada, Map 845A (with marginal notes).

BERRY, N.H., IV and OsBerG, P.H. 1989. A stratigraphic synthesis of eastern Maine and western New Brunswick. In Studies in Maine Geology. Edited by R.D. Tucker and R.G. Marvinney. Maine Geological Survey, 2: Structure and Stratigraphy, pp. 1-32.

CowIE, J.W. and BAsSETT, M.G. 1989. International Union of Geological Sciences. 1989 global stratigraphic chart. Episodes, 12, Special Insert.

DAvis, D.W. 1982. Optimum linear regression and error estimation applied to U.Pb data. Canadian Journal of Earth Sciences, 19, pp. 2141-2149.

Doig, R., Nance, R.D., Murphy, J.B., and Casseday, R.P. 1990. Evidence for Silurian sinistral accretion of Avalon Composite Terrane in Canada. Geological Society of London Journal, 147, pp. 927-930.

Dunning, G.R., Swinden, H.S., Kean, B.F., Evans, D.T.W., and Jenner, G.A. 1991. A Cambrian island arc in Iapetus: geochronology and geochemistry of the Lake Ambrose volcanic Belt, Newfoundland Appalachians. Geological Magazine, 128, pp. 1-17.

Fyffe, L.R. 1990a. Geology of the Potters Lake map area, Charlotte County, New Brunswick. In Project Summaries for 1990. Fifteenth Annual Review of Activies. Edited by S.A. Abbott. New Brunswick Department of Natural Resources and Energy, Mineral Resources, Information Circular 90-2. pp. 19-31.

1990b. Structural trends beneath the Carboniferous cover of southern New Brunswick. In Project Summaries for 1990 , Fifteenth Annual Review of Activities. Edited by S.A. Abbott. New Brunswick Department of Natural Resources and Energy, Mineral Resources, Information Circular 90-2, pp. 32-35.

1991. Geology of the Flume Ridge-Kedron Stream map areas, Charlotte County, New Brunswick. In Project Summaries for 1991. Sixteenth Annual Review of Activities. Edited by S.A. Abbott. New Brunswick Department of Natural Resources and Energy, Mineral Resources, Information Circular 91-2, pp. 12-20.

FYFFE, L.R. and FrICKER, A. 1987. Tectonostratigraphic terrane analysis of New Brunswick. Maritime Sediments and Atlantic Geology, 23, pp. 113-123.

FyFfe, L.R. and Riva, J. 1990. Revised statigraphy of the Cookson Group of southwestern New Brunswick and adjacent Maine. Atlantic Geology, 26, pp. 271-275.

Fyffe, L.R., Stewart, D.B., and Ludman, A. 1988. Tectonic significance of black pelites and basalts in the St. Croix Terrane, coastal Maine and New Brunswick. Maritime Sediments and Atlantic Geology, 24, pp. 281-288.

FyfFe, L.R., van StaAL, C.R., and Winchester, J.A. 1990. Late Precambrian-Early Paleozoic volcanic regimes and associated massive sulphide deposits in the northeastern mainland Appalachians. Canadian Institute of Mining and Metallurgy, Bulletin 83, No. 938, pp. 70-78.

Fyffe, L.R., McLeod, M.J., and Ruitenbero, A.A. 1991. A geotraverse across the St. Croix-Avalon Terrane boundary, 
southern New Brunswick. In New England intercollegiate geological conference guidebook to the geology of the coastal lithotectonic block and neighboring terranes, eastern Maine and southern New Brunswick. Edited by A. Ludman. Department of Geology, Queens College, City University of New York, Flushing, New York, pp. 13-54.

Hamilton, J.B. 1961. Geology of Codys, Queens, and Kings counties, New Brunswick. New Brunswick Department of Lands and Mines, Mines Branch, Geological Note Series, P.M. 59-5, 18 p.

Jafpey, A.J., FlynN, K.F., Glendenin, L.E., Bentley, W.C., and Essling, A.M. 1971. Precision measurements of half-lives and specific activities of ${ }^{235} \mathrm{U}$ and ${ }^{238} \mathrm{U}$. Physical Reviews, $\mathrm{C4}$, pp. 1889-1906.

KROGH, T.E. 1973. A low-contamination method for hydrothermal decomposition of zircon and extraction of $\mathrm{U}$ and $\mathrm{Pb}$ for isotopic age determinations. Geochimica et Cosmochimica Acta, 37, pp. 485-494.

1982. Improved accuracy of U-Pb zircon ages by the creation of more concordant systems using an air abrasion technique. Geochimica et Cosmochimica Acta, 46, pp. 637649.

Leger, A. and Williams, P.F. 1986. Transcurrent faulting history of southern New Brunswick. In Current Research, Part B. Geological Survey of Canada, Paper 86-1B, pp. 111-120.

Ludman, A. 1978. Stratigraphy, structure, and progressive metamorphism of Lower Paleozoic rocks in the Calais area, southeastern Maine. In New England intercollegiate geological conference guidebook for field trips in southeastern Maine and southwestern New Brunswick. Edited by A. Ludman. Queens College Geology Bulletin, 6, pp. 78-101.

1987. Pre-Silurian stratigraphy and tectonic significance of the St. Croix Belt, southeastern Maine. Canadian Journal Of Earth Sciences, 24, pp. 2459-2469.

- 1991a. Revised stratigraphy of the Cookson Group in eastern Maine and southwestern New Brunswick: an alternative view. Atlantic Geology, 27, pp. 49-55.

- 1991b. Revised stratigraphy of the Cookson Group (St. Croix Terrane) eastern Maine and southwestern New Brunswick. In New England intercollegiate geological conference guidebook to the geology of the coastal lithologic block and neighboring terrane, eastern Maine and southern New Brunswick. Edited by A. Ludman. Department of Geology, Queens College, City University of New York, Flushing, New York, pp. 114-132.

McCutcheon, S.R. 1981. Revised stratigraphy of the Long Reach area, southern New Brunswick: Evidence for major, northwestward-directed Acadian thrusting. Canadian Journal of Earth Sciences, 18, pp. 646-656.

McCutcheon, S.R. and Robinson, P.T. 1987. Geological constraints on the genesis of the Maritimes Basin, Atlantic Canada. In Sedimentary Basins and Basin-forming Mechanisms. Edited by C. Beaumont and A.J. Tankard. Canadian Society of Petroleum Geology, Memoir 12, pp. 287-297.

McCutcheon, S.R. and Ruitenberg, A.A. 1987. Geology and mineral deposits of the Annidale-Nerepis area. New Brunswick Department of Natural Resources and Energy, Mineral Resources Division, Memoir 2, 141 p.

MCLEOD, M.J. 1990. Geology, geochemistry and related mineral deposits of the Saint George Batholith; Charlotte, Queens and Kings counties, New Brunswick. New Brunswick Department of Natural Resources and Energy, Mineral Re- sources, Mineral Resource Report 5, 169 p.

McLeod, M.J., Johnson, S.C., and Ruitenberg, A.A. 1989. Compilation and correlation of southern New Brunswick geology, Charlotte, Queens and Kings counties. In Project Summaries for 1989, Fourteenth Annual Review of Activities. Edited by S.A. Abbott. New Brunswick Department of Natural Resources and Energy, Minerals and Energy Division, Information Circular 89-2, pp. 133-141.

1990. Compilation and correlation of southwestern New Brunswick geology, Charlotte, Queens, Kings and Sunbury counties. In Project Summaries for 1990, Fifteenth Annual Review of Activities. Edited by S.A. Abbott. New Brunswick Department of Natural Resources and Energy, Minerals and Energy Division, Information Circular 90-2, pp. 137-147.

1991a. Geological compilation of the Hampstead map area $(21 \mathrm{G} / 9)$, Sussex map area $(21 \mathrm{H} / 12)$, and Codys map area $(21 \mathrm{H} / 13)$, southern New Brunswick. New Brunswick Department of Natural Resources and Energy, Mineral Resources, Plates 90-152, 90-153, 90-154.

McLeod, M.J., Ruitenberg, A.A., and Krogh, T.E. 1991b. A previously unrecognized Lower Ordovician sequence in southern New Brunswick: Evidence for multistage development of Iapetus? (abstract). Atlantic Geoscience Society Colloquium, Amherst, Nova Scotia. Atlantic Geology, 27, p. 157.

McLeod, M.J., Ruitenberg, A.A., and Johnson, S.C. 1991 c. Compilation and correlation of southwestern New Brunswick Geology, Charlotte, Queens, Kings, Saint John, and Sunbury counties. In Project Summaries for 1991, Sixteenth Annual Review of Activities. Edited by S.A. Abbott. New Brunswick Department of Natural Resources and Energy, Mineral Resources Division, Information Circular 91-2, pp. 128-133.

Nance, R.D. 1987. Model for the Precambrian evolution of the Avalon terrane in southern New Brunswick, Canada. Geology, 15, pp. 753-756.

Potter, R.R., Hamilton, J.B., and Davies, J.L. 1979. Geological map of New Brunswick (second edition). New Brunswick Department of Natural Resources, Mineral Resources Branch, Map NR-1.

Roberts, G.C. and Prince, J.D. 1987. The evaluation of the Sheba prospect (21H/13E), Queens County, New Brunswick. Maritime Resource Research Limited report. New Brunswick Department of Natural Resources and Energy, Mineral Resources, Assessment File 473355.

Ruitenberg, A.A. 1967. Stratigraphy, structure and metallization Piskahegan-Rolling Dam area, northem Appalachians, New Brunswick, Canada. Leidse Geologische Mededelingen, 40, pp. 79-120.

1970. Mineralized structures in the Johnson Croft, Annidale, Jordan Mountain, and Black River areas. New Brunswick Department of Natural Resources, Mineral Resources Branch, Report of Investigation 13, $28 \mathrm{p}$.

Ruitenberg, A.A., Johnson, S.C., and FyfFe, L.R. 1990. Epigenetic gold deposits and their tectonic setting in the New Brunswick Appalachians. Canadian Institute of Mining and Metallurgy, Bulletin 83, No. 934, pp. 43-55.

StaCEY, J.S. and Kramers, J.D. 1975. Approximation of terrestrial lead isotope evolution by a two-stage model. Earth and Planetary Science Letters, 26, pp. 207-221.

Thомas, M.D. and Willis, C. 1989. Gravity modeling of the Saint George Batholith and adjacent terrane within the Appalachian Orogen, southern New Brunswick. Canadian Journal of Earth Sciences, 26, pp. 561-576. 
Woods, G. 1990. Assessment report on the Annidale claims (21H/ 13E), Kings County, New Brunswick. PGE Resources Corporation report. New Brunswick Department of Natural Resources and Energy, Mineral Resources, Assessment File
473968.

van Der Pluijm, B.A. and van Staal, C.R. 1988. Characteristics and evolution of the Central Mobile Belt, Canadian Appalachians. Journal of Geology, 96, pp. 535-547. 